\title{
Intercultural Learning in Moroccan Higher Education: A Comparison between Teachers' Perceptions and Students' Expectations
}

\section{Mouhssine Echcharfy ${ }^{1 *}$}

* Correspondence:

M.Echarfy@gmail.com

Department of English, Faculty of

Letters and Humanities, Chouaib

Doukkali University, El Jadida,

Morocco

Received: 24 September 2019

Revision: 6 December 2019

Accepted: 20 December 2019

Published online: 20 March 2020

\begin{abstract}
In light of the new millennium, there has been a growing need for learners who can live and act as intercultural speakers/intermediaries in such a globalized world. This need, therefore, has brought a new learning pedagogy called "Intercultural Learning", aims to provide an ever-lasting learning process to prepare intercultural speakers for cross-cultural encounters. However, the way intercultural learning is perceived by the teachers would differ from the way it is perceived by the students, which may affect the learning outcomes. In this respect, the present study aims to compare teachers' perceptions with students' expectations regarding intercultural learning in Moroccan higher education. To this end, with a total sample of 51 participants (teachers " $\mathrm{N}=25$ " \& students " $\mathrm{N}=26$ "), two Likert scale questionnaires were used. Based on descriptive and inferential statistics, the findings indicated that most of the teachers held positive perceptions by showing a high degree of agreement with different aspects of intercultural learning namely, the cultural aspects of language teaching, the cultural topics covered, the techniques and the assessment methods used in intercultural learning. Regardless of students' disagreement with some aspects of intercultural learning, the results revealed that they showed positive and high expectations about most of the aspects. Furthermore, on the basis of independent samples t-test, the results indicated that the means of the two groups are not significantly different, and so there is no significant difference between teachers' perceptions and learners' expectations regarding intercultural learning. The study provides insightful implications for teachers and learners regarding intercultural learning.
\end{abstract}

Keywords: intercultural learning, globalized world, Moroccan higher education, students' expectations, teachers' perceptions 


\section{Introduction}

\subsection{Background}

A large body of research has realized that language failure is linked with the lack of knowledge regarding the target culture (e.g., Brown, 1994; Byram, 1997; Kramsch, 1993). This indicates that culture and language are inseparable, as they serve one entity. Brown (1994) describes the relation between the two as follows "a language is a part of a culture and a culture is a part of a language; the two are intricately interwoven so that one cannot separate the two without losing the significance of either language or culture" (p.165) (Liddicoat et al., 2003). The absence of either language or culture would result in losing the significance of the other because culture enables the individual to make sense of and understand the world around him/her, as it gives meaning to the language spoken (Brown, 2007). However, culture represents the invisible part of the language without which language is meaningless. It serves as a blueprint of life in that it guides peoples' behaviors in a certain community (Brown, 1994).

Therefore, the incorporation of culture within English as a Foreign Language (EFL) classrooms would be of a great benefit to learners and teachers alike. The advantage of using culture in the classroom, according to Zhao (2010), consists of familiarizing EFL learners with English speaking countries' customs and habits, enabling them to understand the interaction between such social variables, cultivating the students' ability to objectively assess the culture of the target country, and see their own culture from others' perspectives (Byram, 1997; Deardorff, 2004; Yeganeh \& Raeesi, 2015). Stern (1992) reiterates that incorporating culture in language teaching and learning context helps the learner understand the other's perspective. It also helps learners become aware of the way people of the target community think and behave. As a result, the learner is likely to develop an understanding of his/her own and the other culture (Tomlinson, 2001 as cited in Shemshadsara, 2012).

\subsection{Statement of the Problem}

With globalization and the increased social mobility across the world, students should be trained to meet the demands of the 21 st century by developing a number of competencies, including attitudes, knowledge, and skills, to act appropriately in intercultural encounters. However, the teaching of culture remains a problem for practitioners due to the absence of a clear methodology that could help them set appropriate teaching and learning objectives (Leutwyler et al., 2014). By adopting an effective teaching methodology, students would not only learn factual cultural knowledge but also develop their attitudes towards cultural diversity, their knowledge about the world of origin and the target community and their ability to employ such knowledge in real-time communication. Therefore, for better development of intercultural competence, research should be conducted to understand the relationship between teachers' perceptions and learners' expectations of intercultural learning.

Many scholars at the international level have been concerned with teachers and/or students' beliefs of intercultural learning (e.g., Belli, 2018; Tran \& Seepho, 2014). Belli (2018) found that students showed positive attitudes towards the incorporation of culture into the language learning process at the level of the cultural knowledge they are introduced to materials, and their perceptions on the assessment of culture in language classes. On the other hand, Tran and Seepho's (2014) findings revealed that most of the teachers had positive perceptions of incorporating cultural competence in English language teaching. However, the issue at stake is the extent to which teachers' perceptions match learners' expectations of intercultural learning. In this sense, Alimorad and Tajgozari (2016) believe that mismatches between teachers' perceptions and students' expectations may have negative effects on students' satisfaction and, subsequently, on their outcomes. Therefore, due to the scarcity of research on intercultural learning, especially in the Moroccan context, the present study aims to compare teachers' perceptions with students' expectations regarding intercultural learning in Moroccan universities.

\section{Theoretical Perspective/Review of the Literature}

\subsection{Intercultural Learning}

Huber and Reynolds (2014) define intercultural learning as a pedagogy (i.e., content, teaching methods, syllabus and materials, and assessment) that aims to develop learners' intercultural competence in order to encourage intercultural dialogue between communities. According to Lafraya (2011), intercultural learning is referred to the process of acquiring attitudes, knowledge, and skills the learner needs in interaction within intercultural encounters (Cardona et al., 2015). Intercultural learning also involves the learner in a process of "transformation of the self, his/her ability to communicate and to understand communication, and his/her skills for ongoing learning" (Liddicoat et al., 2003, p.16). 
This implies that the major point in intercultural learning is that the learner starts viewing the self and the world differently (Mezirow, 2000 as cited in Jokikokko, 2010); nevertheless, this transformation can be achieved only when the person experiences new intercultural situations in a dialogue with others (Jokokikko, 2010). Thus, intercultural learning helps the learner to develop the ability to communicate effectively and appropriately in different multicultural contexts. It helps the learner to develop the ability to acculturate and live within culturally diverse communities. It has a significant role in training citizens who can function appropriately in the global world and reshape societies where they live (Sandu, 2013). To this end, several tasks and activities are proposed to facilitate intercultural learning.

In intercultural learning, experiential activities are usually designed around the themes covered throughout the course. First, role-play and simulation activities have been the most effective activities that promote interpersonal communication and interaction since the communicative language teaching era, as they allow learners to experience a new way of thinking, new norms, and a new identity (Huber \& Reynolds, 2014). By implementing such activities, students can develop the ability to "act differently from their usual ways, norms, and standards" (Huber \& Reynolds, 2014, p.4). Second, critical incidents or scenarios are also important to develop students' intercultural competence, as they promote critical thinking. Corbett (2003) views a critical incident as an incident in which "1) a conflict about values, goals, or meaning arises; 2) the solution to the conflict is not immediately apparent, or it is controversial; and (3) the cultural context of the conflict is clearly and concisely presented" (p.111). This suggests that critical incidents prompt students' critical thinking and develop their evaluation and mediation skills.

Third, discussions and debates are believed to be the most useful teaching methods to promote intercultural awareness (e.g., Byram et al., 2002; Corbett, 2003; Lázár et al., 2007). One of the major benefits of this activity is that it provides learning opportunities for learners to share and discuss ideas and opinions about different intercultural issues (Boggs et al., 2007; Vigier \& Le Floch, 2011). Given the fact that students reflect on their learning experience in the classroom through discussions and debates, it is also possible for learners to reflect on their intercultural learning experience through portfolio outside the classroom (Byram et al., 2002, Byram et al., 2009; Council of Europe, 2001; Lázár et al., 2007). The portfolio is defined as “a purposeful collection of work that provides information about someone's efforts, progress, or achievement in a given area. It is a learning as well as assessment tool" (Richards \& Schmidt, 2010, p.443). It is highly recommended to implement portfolios in the intercultural learning process as it plays two major roles: an opportunity for learners to reflect on their learning experience and a formative assessment tool that enables teachers observe the learners' progress throughout the course.

In the same line of thought, assessment methods and formats vary depending on the objectives of the course (Làzàr et al., 2007). These assessment methods could be formative or summative, direct or indirect, and objective or subjective. Therefore, clearly formulated objectives are essential for proper assessment (Byram, 1997). Many researchers refer objective testing to the direct assessment as it requires direct responses to avoid any likely subjectivity (e.g., Byram et al., 2002; Corbett, 2003; Làzàr et al., 2007). This includes multiple-choice questions, matching, true/false questions, and the like. On the other hand, subjective testing refers to the indirect assessment as it allows the grader to make judgments on students' responses. Writing essays, for example, calls upon the judgment of the marker/examiner (Corbett, 2003). As for formative assessment, it is an ongoing process that gives learners the chance to reflect on their intercultural experience, give them guidance, and receive feedback during the course (e.g., portfolio) (Corbett, 2003; Làzàr et al., 2007). This does not mean that summative assessment is needless. Yet, this latter is meant to measure learners' achievements at the end of the course (Brindley, 2001 as cited in Skopinskaja, 2009).

The techniques and the assessment methods used in intercultural learning along with the topics covered and different cultural teaching practices would, inevitably, help learners shift from ethnocentric to ethnorelative perspective so as to amalgamate different cultures in order to support world solidarity, social cohesion, and respect the plurality of cultural identities (Cunha \& Gomes, 2008; Sandu, 2013). In this sense, intercultural learning provides learners with the necessary skills, knowledge, and attitudes they need to deconstruct and critically interpret an ethnocentric perspective, to impede the social injustice, and to maintain relationships in such a globalized world (Neuner, 2012). Thus, education role consists of preparing learners to live together with people of different cultures within a contemporary heterogeneous world that is based on maintaining relationships, interacting, and understanding each other on the basis of mutual respect (Byram, 1997; Byram et al., 2002; Neuner, 2012). According to Lu and Corbett (2012), intercultural language education addresses "the now-common situation in which individuals from different cultural backgrounds find themselves living and working together, discursively renegotiating their identities and critically reflecting on and reshaping their own ideological and value systems" (p.331). In this vein, there is an urgent 
need for the implementation of intercultural learning in education so as to develop intercultural competence as one of the most crucial 21 st-century skills.

\subsection{Perceptions of Intercultural Competence}

Recent research findings have revealed the importance of integrating culture in foreign language teaching. However, there is a clear absence of studies in the Moroccan context. Some selected studies are reviewed below. Belli (2018) conducted a study that aimed to explore the ELT students' cultural awareness, attitudes and ideas towards the concept of culture, the embodiment of culture into the language teaching, and their opinions on the place of cultural elements in their own language-learning environment. The study yielded positive results as the majority of the ELT students displayed positive attitudes towards the incorporation of culture into the language learning process in terms of their reactions to the cultural knowledge they are introduced through teachers, materials, and course books and their perceptions on the assessment of culture in language classes.

Another study by Farooq, Soomro, and Umer (2018) focused on identifying EFL teachers' perceptions of and attitudes towards the teaching of culture in the English language classroom. It was found that the EFL teachers in Saudi universities understand the importance of culture in teaching English and they are aware of integrating culture and language in their teaching. They understand differences in various cultures and know-how to discuss such cultural differences and incorporate these differences in the curriculum which they think is the starting point to teach and develop a multicultural learning environment to develop cross-cultural awareness.

An attempt was made by Israelsson (2016) to investigate how teachers of English in upper secondary schools in Sweden interpret the concept of intercultural competence and their view of culture in English language teaching. The results suggested that teachers lack theoretical background and central guidance with regards to intercultural competence and do not always integrate language and culture into an intercultural model of the English language pedagogy. Tran and Seepho (2014) made an attempt to investigate EFL teachers' perceptions and their incorporation of cultural competence in ELT. The results showed that EFL teachers had good understanding of cultural competence, and were somewhat familiar with the target language culture. Additionally, most of them had positive perceptions of incorporating cultural competence in ELT, yet a small gap seemed to appear between teachers' perceptions and their teaching practices.

In the same vein, Hui (2010) also conducted a study which aimed to investigate teachers' perspectives on cultural teaching in terms of the teaching objectives of language and culture; teachers' understanding of 'culture'; the cultural topics they favor to teach in the classroom; the techniques they use to teach culture; the time allocated to culture teaching, and finally their attitudes towards intercultural communicative competence. The results revealed encouraging signs of teachers and college trainers' willingness to engage in cultural teaching, but the results also reflected teething problems to fully involve cultural communicative competence in the classrooms.

In light of the studies presented above, it shows that most of the studies conducted did not investigate teachers and learners' perceptions regarding intercultural learning. Rather, most of them investigated perceptions regarding intercultural competence. Therefore, the present study is an attempt to investigate teachers' perceptions and learners' expectations regarding four aspects of intercultural learning namely, the cultural aspects of language teaching, the cultural topics covered, the techniques, and the assessment methods used in intercultural learning. In line with the objective of the study, the present study is informed by the following research questions:

1) What perceptions do teachers hold about intercultural learning?

2) What expectations do students have regarding intercultural learning?

3) Is there a mismatch between students' expectations and teachers' perceptions?

\section{Methodology}

\subsection{Research Design}

The present study adopts an exploratory design. The study aims at exploring teachers' perceptions and students' expectations regarding intercultural learning. It also aims to compare teachers' perceptions and students' expectations regarding intercultural learning. The data were quantified for the sake of using descriptive and inferential statistics. 


\subsection{Subjects and Research Setting}

On the basis of convenience sampling, the present study was conducted of a scale of fifty one participants: twenty six students and twenty five teachers. Teachers and students were chosen from different Moroccan universities due to their availability and willingness to collaborate. The universities included were Ibn Zohr University, Agadir, Mohamed V University, Rabat and Ibn Tofail University, Kenitra. Most of the teachers included have already taught culture throughout their career. The study involved English major first year students ( $1^{\text {st }}$ semester), as they had not been introduced to a culture course.

\subsection{Instruments}

The study utilized two five-point Likert scale questionnaires ( $5=$ strongly agree $\rightarrow 1=$ strongly disagree); one was for teachers and the other one for students. The questionnaires were divided into four sections: the cultural aspects of language teaching, the cultural topics covered, the techniques, and the assessment methods used in intercultural learning. Each questionnaire included 30 questions.

\subsection{Procedure of the Study}

On the basis of convenience sampling, teachers and students from different Moroccan universities were chosen to participate in the present study. The data was collected by having a meeting with some English major first-year students who showed a willingness to fill in the questionnaire. Students from different universities were invited to complete the questionnaire online while others, those of teachers', were filled out online due to time constraints and their place of residence.

\subsection{Data Analysis}

In light of the research questions, the data were analyzed quantitatively using descriptive statistics in order to explore teachers' perceptions and students' expectations regarding intercultural learning. The data were also analyzed using inferential statistics, more specifically, Independent samples t-test so as to compare teachers' perceptions with students' expectations regarding intercultural learning.

\section{Results}

\subsection{RQ1: What Perceptions Do Teachers Hold about Intercultural Learning?}

Table 1 shows the teachers' perceptions regarding the cultural aspects of language teaching. The results indicate that the majority of the teachers' responses regarding all aspect of intercultural competence, i.e., attitudes, knowledge, and skills, range from "strongly agree" to "agree", especially, items 5, 8, and 9. Yet, those who "agree" with the statements outweigh those who "strongly agree." Given that most of respondents hold positive perceptions regarding Items $2,3,4,6$, and 7 , a high range of respondents $(44 \%$ and $36 \%)$ respectively "agree" and "strongly agree" that attitude toward incidents caused by racial prejudices or intolerance should be encouraged. As a response to item $8,40 \%$ of the teachers "agree" and $40 \%$ "strongly agree" that learners should be encouraged to understand, evaluate, and relate to ambiguous and uncertain intercultural situations. Again, $40 \%$ and $48 \%$ of teachers respectively "agree" and "strongly agree" that the teachers should create an intercultural environment in the classroom. 
Table 1. Teachers' perceptions regarding the cultural aspects of language teaching

\begin{tabular}{|c|c|c|c|c|c|}
\hline & $\begin{array}{l}\text { Strongly } \\
\text { agree }\end{array}$ & Agree & Neutral & Disagree & $\begin{array}{l}\text { Strongly } \\
\text { disagree }\end{array}$ \\
\hline $\begin{array}{l}\text { 1) Help learners to develop intercultural } \\
\text { awareness }\end{array}$ & $28 \%$ & $32 \%$ & $40 \%$ & $0 \%$ & $0 \%$ \\
\hline $\begin{array}{l}\text { 2) Ask learners to establish similarities and } \\
\text { differences between their own culture and } \\
\text { the other culture. }\end{array}$ & $4 \%$ & $60 \%$ & $36 \%$ & $0 \%$ & $0 \%$ \\
\hline $\begin{array}{l}\text { 3) Tell learners what I heard or read about } \\
\text { foreign country or culture. }\end{array}$ & $12 \%$ & $52 \%$ & $36 \%$ & $0 \%$ & $0 \%$ \\
\hline $\begin{array}{l}\text { 4) Encourage learners to further investigate } \\
\text { into the cultural topics dealt with in class and } \\
\text { report on the findings. }\end{array}$ & $24 \%$ & $56 \%$ & $16 \%$ & $4 \%$ & $0 \%$ \\
\hline $\begin{array}{l}\text { 5) Encourage learners to express their } \\
\text { attitudes towards incidents caused by } \\
\text { racial/religious/gender prejudices or } \\
\text { intolerance. }\end{array}$ & $36 \%$ & $44 \%$ & $20 \%$ & $0 \%$ & $0 \%$ \\
\hline $\begin{array}{l}\text { 6) Encourage learners to discuss negative } \\
\text { stereotypes about the members of other } \\
\text { cultures and their possible effects. }\end{array}$ & $24 \%$ & $40 \%$ & $36 \%$ & $0 \%$ & $0 \%$ \\
\hline $\begin{array}{l}\text { 7) Encourage the development of skills, } \\
\text { attitudes and awareness of values as much as } \\
\text { intercultural knowledge }\end{array}$ & $32 \%$ & $40 \%$ & $28 \%$ & $0 \%$ & $0 \%$ \\
\hline $\begin{array}{l}\text { 8) Help learners to understand, evaluate and } \\
\text { relate to ambiguous and uncertain } \\
\text { intercultural situations. }\end{array}$ & $40 \%$ & $40 \%$ & $20 \%$ & $0 \%$ & $0 \%$ \\
\hline $\begin{array}{l}\text { 9) Provide an intercultural environment } \\
\text { where learners communicate and interact }\end{array}$ & $40 \%$ & $48 \%$ & $12 \%$ & $0 \%$ & $0 \%$ \\
\hline $\begin{array}{l}\text { 10) Facilitate the learning process by } \\
\text { tailoring and adapting messages to learners' } \\
\text { levels }\end{array}$ & $28 \%$ & $32 \%$ & $40 \%$ & $0 \%$ & $0 \%$ \\
\hline
\end{tabular}

As for Table 2, it shows teachers' perceptions regarding the techniques used to instruct culture. A significant proportion of respondents show a considerable agreement with the techniques used to instruct culture. Most of the respondents show positive perceptions regarding the activities and techniques used to prompt interaction and reflection while only a minority shows the opposite. The majority of respondents considerably agree that exposing students to pictures and films before discussion should be highly considered in intercultural learning (items 3 \& 4). A large number of respondents show their agreement with the use of techniques that involve discussions on problems-solving or establishing similarities and differences between two different cultures. The results also show that the majority of the respondents positively perceive portfolio and critical incidents as major techniques to instruct culture as they "agree" and "strongly agree" with item 9 and 10. 
Table 2. Teachers' perceptions regarding the techniques used to instruct culture

\begin{tabular}{|c|c|c|c|c|c|}
\hline & $\begin{array}{l}\text { Strongly } \\
\text { agree }\end{array}$ & Agree & Neutral & Disagree & $\begin{array}{l}\text { Strongly } \\
\text { disagree }\end{array}$ \\
\hline $\begin{array}{l}\text { 1) Ask students to act out what they learn in terms of } \\
\text { learning culture. }\end{array}$ & $24 \%$ & $36 \%$ & $36 \%$ & $4 \%$ & $0 \%$ \\
\hline 2) Ask students to recite some dialogues. & $20 \%$ & $28 \%$ & $44 \%$ & $4 \%$ & $4 \%$ \\
\hline $\begin{array}{l}\text { 3) Show students film videos and discuss what they } \\
\text { watch. }\end{array}$ & $36 \%$ & $40 \%$ & $24 \%$ & $0 \%$ & $0 \%$ \\
\hline $\begin{array}{l}\text { 4) Show students pictures or cartoons having cultural } \\
\text { images and let them discuss them. }\end{array}$ & $24 \%$ & $48 \%$ & $28 \%$ & $0 \%$ & $0 \%$ \\
\hline $\begin{array}{l}\text { 5) Do role-plays/simulations with the aim of solving } \\
\text { the problems involved. }\end{array}$ & $16 \%$ & $40 \%$ & $36 \%$ & $8 \%$ & $0 \%$ \\
\hline $\begin{array}{l}\text { 6) Ask students to discuss misunderstandings and } \\
\text { conflicts between cultures in groups }\end{array}$ & $20 \%$ & $56 \%$ & $20 \%$ & $4 \%$ & $0 \%$ \\
\hline $\begin{array}{l}\text { 7) Ask students to discuss similarities and } \\
\text { differences between their culture and the other } \\
\text { culture in small groups. }\end{array}$ & $24 \%$ & $52 \%$ & $24 \%$ & $0 \%$ & $0 \%$ \\
\hline $\begin{array}{l}\text { 8) Ask students to discuss intercultural issues } \\
\text { through debates. }\end{array}$ & $24 \%$ & $24 \%$ & $36 \%$ & $12 \%$ & $4 \%$ \\
\hline $\begin{array}{l}\text { 9) Ask students to write diaries/journals of their } \\
\text { intercultural learning experience at home } \\
\text { (portfolios). }\end{array}$ & $28 \%$ & $40 \%$ & $28 \%$ & $4 \%$ & $0 \%$ \\
\hline $\begin{array}{l}\text { 10) Provide students with critical incidents and } \\
\text { scenarios to reflect on and discuss intercultural } \\
\text { issues. }\end{array}$ & $24 \%$ & $40 \%$ & $20 \%$ & $12 \%$ & $4 \%$ \\
\hline
\end{tabular}

Table 3 reveals the teachers' perceptions regarding the content favored to be taught. As it clearly shown below, the majority of the respondents favor cultural contents that are linked with practices and products, in addition to the implementation of authentic materials. Despite the significant percentage of respondents who see that it is necessary to teach learners about perspectives of the target culture, $64 \%$ of teachers lean toward teaching learners about practices of the target cultures. Teaching learners about products of the target culture is also agreed upon by $36 \%$ of the respondents and still $48 \%$ of them strongly agree. Last but not least, a considerable amount of respondents show agreement and strong agreement with the provision of authentic materials. 
Table 3. Teachers' perceptions regarding the content favored to be taught

\begin{tabular}{|c|c|c|c|c|c|}
\hline & $\begin{array}{l}\text { Strongly } \\
\text { agree }\end{array}$ & Agree & Neutral & Disagree & $\begin{array}{l}\text { Strongly } \\
\text { disagree }\end{array}$ \\
\hline $\begin{array}{l}\text { 1) Teach learners about perspectives of } \\
\text { the target culture (e.g. Values and beliefs; } \\
\text { identity; religious life \& tradition) }\end{array}$ & $24 \%$ & $40 \%$ & $24 \%$ & $12 \%$ & $0 \%$ \\
\hline $\begin{array}{l}\text { 2) Teach learners about practices of the } \\
\text { target culture (behavioral and } \\
\text { interactional skills) }\end{array}$ & $28 \%$ & $64 \%$ & $8 \%$ & $0 \%$ & $0 \%$ \\
\hline $\begin{array}{l}\text { 3) Teach learners about products of the } \\
\text { target culture (e.g., literature works, } \\
\text { music food, etc.) }\end{array}$ & $48 \%$ & $36 \%$ & $16 \%$ & $0 \%$ & $0 \%$ \\
\hline $\begin{array}{l}\text { 4) Provide information that is true and } \\
\text { authentic, and which learners need to } \\
\text { know about the other culture. }\end{array}$ & $32 \%$ & $44 \%$ & $20 \%$ & $4 \%$ & $0 \%$ \\
\hline
\end{tabular}

Table 4 presents teachers' perceptions regarding the assessment methods. High range of respondents shows positive perceptions regarding the implementation of psychometric tests, oral tests, and portfolios. The results show that significant proportion of teachers assert that essays, observation, and the combination of both formative and summative assessment should be used as assessment methods to evaluate students' performance in intercultural learning. However, the majority of respondents (48\%) agree that the use of psychometric tests should be used to develop intercultural competence whereas $12 \%$ of them "strongly agree." The results also reveal that a considerable number of teachers (44\%) agree with the use of interview or oral tests to evaluate students' performance while over $24 \%$ marked "strongly agree." For the implementation of portfolios as assessment methods, $40 \%$ and $16 \%$ respectively "agree" and "strongly agree."

Table 4. Teachers' perceptions regarding the assessment methods used

\begin{tabular}{llcccc}
\hline & $\begin{array}{l}\text { Strongly } \\
\text { agree }\end{array}$ & Agree & Neutral & Disagree & $\begin{array}{l}\text { Strongly } \\
\text { disagree }\end{array}$ \\
\hline $\begin{array}{l}\text { 1) Evaluate students' performance through } \\
\text { essays. }\end{array}$ & $4 \%$ & $36 \%$ & $36 \%$ & $16 \%$ & $8 \%$ \\
$\begin{array}{l}\text { 2) Evaluate students' performance through } \\
\text { psychometric tests (e.g., T/F questions \& } \\
\text { MCQ) }\end{array}$ & $12 \%$ & $48 \%$ & $28 \%$ & $8 \%$ & $4 \%$ \\
$\begin{array}{l}\text { 3) Evaluate students' performance through } \\
\text { an oral test (Interview) }\end{array}$ & $24 \%$ & $44 \%$ & $16 \%$ & $16 \%$ & $0 \%$ \\
$\begin{array}{l}\text { 4) Evaluate students' performance through } \\
\text { portfolios. }\end{array}$ & $16 \%$ & $40 \%$ & $28 \%$ & $12 \%$ & $4 \%$ \\
$\begin{array}{l}\text { 5) Evaluate students' performance through } \\
\text { observation. }\end{array}$ & $16 \%$ & $36 \%$ & $44 \%$ & $4 \%$ & $0 \%$ \\
$\begin{array}{l}\text { 6) Evaluate students' performance on the } \\
\text { basis of both formative and summative } \\
\text { assessment methods. }\end{array}$ & $28 \%$ & $36 \%$ & $28 \%$ & $8 \%$ & $0 \%$ \\
\hline
\end{tabular}




\subsection{RQ2: What Expectations Do Students Have Regarding Intercultural Learning?}

The table below shows students' expectations regarding the cultural aspects of language teaching. The results show that the majority of students hold high expectations regarding cultural aspect of language teaching. As it is clearly indicated below, students show a considerable and strong agreement with items 5 and 9 . Regardless of the number of respondents who hold positive expectations regarding items $1,2,3,7$, and 10, a large majority of students show high expectations about attitudes towards incidents caused by racial or religious prejudices or intolerance. Even more significantly, more than half of the respondents highly expect an intercultural environment where they can interact and communicate in cross cultural encounters.

Table 5. Students' expectations regarding the cultural aspects of language teaching

\begin{tabular}{|c|c|c|c|c|c|}
\hline & $\begin{array}{l}\text { Strongly } \\
\text { agree }\end{array}$ & Agree & Neutral & Disagree & $\begin{array}{l}\text { Strongly } \\
\text { disagree }\end{array}$ \\
\hline 1) I expect to develop intercultural awareness & $42,3 \%$ & $46,2 \%$ & $3 \%$ & $0 \%$ & $0 \%$ \\
\hline $\begin{array}{l}\text { 2) I expect the teacher to encourage establishing } \\
\text { similarities and differences between our own } \\
\text { culture and the other culture. }\end{array}$ & $46,2 \%$ & $38,5 \%$ & $15,4 \%$ & $0 \%$ & $0 \%$ \\
\hline $\begin{array}{l}\text { 3) I expect the teacher to tell what he heard or read } \\
\text { about the other country or culture. }\end{array}$ & $23,1 \%$ & $57,7 \%$ & $0 \%$ & $0 \%$ & $0 \%$ \\
\hline $\begin{array}{l}\text { 4) I expect the teacher to encourage further } \\
\text { investigation into the cultural topics dealt with in } \\
\text { class and report on the findings. }\end{array}$ & $15,4 \%$ & $30,8 \%$ & $42,3 \%$ & $7,7 \%$ & $3,8 \%$ \\
\hline $\begin{array}{l}\text { 5) I expect the teacher to encourage expressing } \\
\text { learners' attitudes towards incidents caused by } \\
\text { racial/religious/gender prejudices or intolerance. }\end{array}$ & $61,5 \%$ & $19,2 \%$ & $15,4 \%$ & $3,8 \%$ & $0 \%$ \\
\hline $\begin{array}{l}\text { 6) I expect the teacher to encourage the discussion } \\
\text { of negative stereotypes about the members of other } \\
\text { culture and their possible effects. }\end{array}$ & $19,2 \%$ & $38,5 \%$ & $34,6 \%$ & $3,8 \%$ & $3,8 \%$ \\
\hline $\begin{array}{l}\text { 7) I expect the teacher to encourage the } \\
\text { development of skills, attitudes and awareness of } \\
\text { values as much as intercultural knowledge. }\end{array}$ & $42,3 \%$ & $50,0 \%$ & $7,7 \%$ & $0 \%$ & $0 \%$ \\
\hline $\begin{array}{l}\text { 8) I expect the teacher to help learners to } \\
\text { understand, evaluate and relate to ambiguous and } \\
\text { uncertain intercultural situations. }\end{array}$ & $11,5 \%$ & $30,8 \%$ & $53,8 \%$ & $3,8 \%$ & $0 \%$ \\
\hline $\begin{array}{l}\text { 9) I expect the teacher to provide an intercultural } \\
\text { environment where learners can communicate and } \\
\text { interact. }\end{array}$ & $69,2 \%$ & $19,2 \%$ & $7,7 \%$ & $3,8 \%$ & $0 \%$ \\
\hline $\begin{array}{l}\text { 10) I expect the teacher to facilitate the learning } \\
\text { process by tailoring and adapting messages to } \\
\text { learners' levels }\end{array}$ & $42,3 \%$ & $15,3 \%$ & $19,2 \%$ & $23,1 \%$ & $0 \%$ \\
\hline
\end{tabular}

Table 6 shows students' expectations regarding the techniques used to instruct culture. The results indicate that most of the respondents do have high expectations regarding items 3,6 , and 8 as they "strongly agree" while, generally, the majority show positive expectations regarding all the items as they "agree." The majority of students highly expect activities that prompt discussions and reflections (e.g., Videos, misunderstanding and conflicts, intercultural issues through debates) (items 3, 6, \& 8). For the other items, a significant number of students "agree" with the 
implementation of role-plays and simulations, discussions, critical incidents and scenarios. However, a total of $30,8 \%$ and $3,8 \%$ of the respondents do not expect writing diaries and journals of their intercultural learning experience (portfolio) as they "disagree" and "strongly disagree" respectively (item 9).

Table 6. Students' expectations regarding the techniques used to instruct culture

\begin{tabular}{|c|c|c|c|c|c|}
\hline & $\begin{array}{l}\text { Strongly } \\
\text { agree }\end{array}$ & Agree & Neutral & Disagree & $\begin{array}{l}\text { Strongly } \\
\text { disagree }\end{array}$ \\
\hline $\begin{array}{l}\text { 1) I expect to act out what they learn in } \\
\text { terms of learning culture in order to } \\
\text { develop intercultural awareness. }\end{array}$ & $19,2 \%$ & $46,2 \%$ & $26,2 \%$ & $3.8 \%$ & $3.8 \%$ \\
\hline 2) I expect to recite some dialogues. & $15,4 \%$ & $26,9 \%$ & $38,5 \%$ & $7,7 \%$ & $11,5 \%$ \\
\hline $\begin{array}{l}\text { 3) I expect to watch film videos and } \\
\text { discuss what learners watch. }\end{array}$ & $42,3 \%$ & $30,8 \%$ & $23,1 \%$ & $3,8 \%$ & \\
\hline $\begin{array}{l}\text { 4) I expect to see pictures or cartoons } \\
\text { having cultural images and let us discuss } \\
\text { them. }\end{array}$ & $15,4 \%$ & $42,3 \%$ & $23,1 \%$ & $11,5 \%$ & $7,7 \%$ \\
\hline $\begin{array}{l}\text { 5) I expect to do role-plays/simulations } \\
\text { with the aim of solving the problems } \\
\text { involved. }\end{array}$ & $15,4 \%$ & $26,9 \%$ & $46,2 \%$ & $11,5 \%$ & $0 \%$ \\
\hline $\begin{array}{l}\text { 6) I expect to discuss misunderstandings } \\
\text { and conflicts between cultures in groups. }\end{array}$ & $46,2 \%$ & $34,6 \%$ & $15,4 \%$ & $3,8 \%$ & $0 \%$ \\
\hline $\begin{array}{l}\text { 7) I expect to discuss similarities and } \\
\text { differences between our culture and the } \\
\text { other culture in small groups. }\end{array}$ & $34,6 \%$ & $42,3 \%$ & $15,4 \%$ & $3,8 \%$ & $3,8 \%$ \\
\hline $\begin{array}{l}\text { 8) I expect to discuss intercultural issues } \\
\text { through debates. }\end{array}$ & $38,5 \%$ & $23,1 \%$ & $19,2 \%$ & $19,2 \%$ & $0 \%$ \\
\hline $\begin{array}{l}\text { 9) I expect to write diaries/journals of our } \\
\text { intercultural learning experience at home } \\
\text { (portfolios). }\end{array}$ & $15,4 \%$ & $19,2 \%$ & $30,8 \%$ & $30,8 \%$ & $3,8 \%$ \\
\hline $\begin{array}{l}\text { 10) I expect to get exposed to critical } \\
\text { incidents and scenarios to reflect on and } \\
\text { discuss intercultural issues. }\end{array}$ & $15,4 \%$ & $23,1 \%$ & $42,3 \%$ & $19,2 \%$ & $0 \%$ \\
\hline
\end{tabular}

As for Table 7, it shows students expectations regarding the content favored to be covered. The table clearly demonstrates that the majority of respondents who hold positive and high expectations outweigh those who do not. The results reveal that significant amount of respondents do expect to learn about perspectives, practices, and products. $57,7 \%$ of them "agree" as they expect to learn about perspectives of the target culture while $30,8 \%$ "strongly agree" and so they hold high expectations. The results also show that half of the respondents (50\%) show their agreement with learning about the practices of the target culture while some of them $(26,9 \%)$ "strongly agree" as they have high expectations. Similarly, 26, $9 \%$ of the respondents show they strong agreement with learning about the products of the target culture while more than a half of the students $(61,5 \%)$ "agree." The majority of respondents $(69,2 \%)$ highly expect to receive information that is true and authentic as they "strongly agree" whereas $23,1 \%$ "agree." 
Table 7. Students' expectations regarding the content favored to be covered

\begin{tabular}{|c|c|c|c|c|c|}
\hline & $\begin{array}{l}\text { Strongly } \\
\text { agree }\end{array}$ & Agree & Neutral & Disagree & $\begin{array}{l}\text { Strongly } \\
\text { disagree }\end{array}$ \\
\hline $\begin{array}{l}\text { 1) I expect to learn about perspectives of } \\
\text { the target culture (e.g. Values and beliefs; } \\
\text { identity; religious life } \& \text { tradition) }\end{array}$ & $30,8 \%$ & $57,7 \%$ & $11,5 \%$ & $0 \%$ & $0 \%$ \\
\hline $\begin{array}{l}\text { 2) I expect to learn about practices of the } \\
\text { target culture (behavioral and } \\
\text { interactional skills) }\end{array}$ & $26,9 \%$ & $50 \%$ & $19,2 \%$ & $3,8 \%$ & $0 \%$ \\
\hline $\begin{array}{l}\text { 3) I expect to learn about products of the } \\
\text { target culture (e.g., literature works, } \\
\text { music food, etc.) }\end{array}$ & $26,9 \%$ & $61,5 \%$ & $11,5 \%$ & $0 \%$ & $0 \%$ \\
\hline $\begin{array}{l}\text { 4) I expect to receive information that is } \\
\text { true and authentic, and which we need to } \\
\text { know about the other culture. }\end{array}$ & $69,2 \%$ & $23,1 \%$ & $3,8 \%$ & $3,8 \%$ & $0 \%$ \\
\hline
\end{tabular}

The table below shows students' expectations regarding the assessment methods used in intercultural learning. The majority of the respondents $(30,8 \%)$ highly expect to be evaluated through psychometric test as they "strongly agree", with 19, 2 of them who "agree." High expectations are also observed in students' responses to item 3. A total of 34, $6 \%$ "strongly agree" to be evaluated through oral tests, 19, 2\% "agree." For item 5, half of the sample (50\%) asserts that they expect classroom observation as a means of assessment, 15, 4\% "agree." Finally, 30, 8\% expect to be evaluated through both formative and summative assessment methods as they "agree" while $26 \%$ "strongly agree." However, a significant proportion of students show strong disagreement with the items.

Table 8. Students' expectations regarding the assessment methods

\begin{tabular}{|c|c|c|c|c|c|}
\hline & $\begin{array}{l}\text { Strongly } \\
\text { agree }\end{array}$ & Agree & Neutral & Disagree & $\begin{array}{l}\text { Strongly } \\
\text { disagree }\end{array}$ \\
\hline $\begin{array}{l}\text { 1) I expect to be evaluated through } \\
\text { essays. }\end{array}$ & $26,9 \%$ & $26,9 \%$ & $26,9 \%$ & $11,5 \%$ & $7,7 \%$ \\
\hline $\begin{array}{l}\text { 2) I expect to receive psychometric tests } \\
\text { (e.g., T/F questions \& MCQ) }\end{array}$ & $30,8 \%$ & $26,9 \%$ & $30,8 \%$ & $7,7 \%$ & $3,8 \%$ \\
\hline $\begin{array}{l}\text { 3) I expect to be evaluated through an } \\
\text { oral test (Interview) }\end{array}$ & $34,6 \%$ & $19,2 \%$ & $19,2 \%$ & $15,4 \%$ & $11,5 \%$ \\
\hline $\begin{array}{l}\text { 4) I expect to write journals and submit } \\
\text { them for evaluation in a form of } \\
\text { portfolio. }\end{array}$ & $11,5 \%$ & $26,9 \%$ & $34,6 \%$ & $15,4 \%$ & $11,5 \%$ \\
\hline $\begin{array}{l}\text { 5) I expect to be evaluated through } \\
\text { classroom observation. }\end{array}$ & $15,4 \%$ & $50 \%$ & $15,4 \%$ & $15,4 \%$ & $3,8 \%$ \\
\hline $\begin{array}{l}\text { 6) I expect to be evaluated through } \\
\text { formative and summative assessment } \\
\text { methods. }\end{array}$ & $26,0 \%$ & $30,8 \%$ & $23,1 \%$ & $7,7 \%$ & $11,5 \%$ \\
\hline
\end{tabular}




\subsection{RQ 3: Is There a Mismatch between Students' Expectations and Teachers' Perceptions?}

Table 9 reveals a comparison between teachers' perceptions and students' expectations Means by questionnaire items. Starting with the first section of cultural aspect of language teaching, the results indicate that there a mismatch between teachers and students' Means scores. Thus, it is clearly shown that students' expectations outweigh teachers' perceptions. This indicates that students hold high expectations regarding cultural aspects of language teaching, especially, items 1, 2, and 3 in comparison with teachers' perceptions. As for the techniques used to instruct culture, there is an inconsiderable difference between teachers and students' means scores, except some items namely, items 4, 6, 9, and10, yet item 6 (Students' $M=4,23$ > Teachers' $M=3,92$ ) shows a remarkable difference. As shown below, students' scores regarding their expectations of learning about perspectives outperform that of teachers' (Students' $M=4,19>$ Teachers' $M=3,76$ ). Finally yet importantly, students' means scores slightly differ from teachers' mean scores regarding the assessment methods.

Table 9. Comparison of teachers' perceptions and students' expectations means by questionnaire item.

\begin{tabular}{|c|c|c|}
\hline Items & $\begin{array}{l}\text { Teachers' } M \\
(n=25)\end{array}$ & $\begin{array}{l}\text { Students' M } \\
(\mathrm{n}=26)\end{array}$ \\
\hline \multicolumn{3}{|c|}{ Cultural aspects of language teaching } \\
\hline Item 1 & 3,88 & 4,31 \\
\hline Item 2 & 3,68 & 4,31 \\
\hline Item 3 & 3,76 & 4,04 \\
\hline Item 4 & 4,00 & 3,46 \\
\hline Item 5 & 4,16 & 4,38 \\
\hline Item 6 & 3,88 & 3,65 \\
\hline Item 7 & 4,04 & 4,35 \\
\hline Item 8 & 4,20 & 3,50 \\
\hline Item 9 & 4,28 & 4,54 \\
\hline Item 10 & 3,88 & 3,77 \\
\hline \multicolumn{3}{|c|}{ Techniques used to instruct culture } \\
\hline Item 1 & 3,80 & 3,73 \\
\hline Item 2 & 3,56 & 3,27 \\
\hline Item 3 & 4,12 & 4,12 \\
\hline Item 4 & 3,96 & 3,46 \\
\hline Item 5 & 3,64 & 3,46 \\
\hline Item 6 & 3,92 & 4,23 \\
\hline Item 7 & 4,00 & 4,00 \\
\hline Item 8 & 3,52 & 3,81 \\
\hline Item 9 & 3,92 & 3,12 \\
\hline Item10 & 3,68 & 3,35 \\
\hline \multicolumn{3}{|c|}{ Cultural content favored to teach in the classroom } \\
\hline Item 1 & 3,76 & 4,19 \\
\hline
\end{tabular}




\begin{tabular}{lll}
\hline Item 2 & 4,20 & 4,00 \\
Item 3 & 4,32 & 4,15 \\
Item 4 & 4,04 & 4,58 \\
Assessment methods & & \\
Item 1 & 3,12 & 3,54 \\
Item 2 & 3,56 & 3,73 \\
Item 3 & 3,76 & 3,50 \\
Item 4 & 3,52 & 3,12 \\
Item 5 & 3,64 & 3,58 \\
Item 6 & 3,84 & 3,54 \\
\hline
\end{tabular}

Having considered the Mean score of each item, the overall results reveal that there is a very small difference between the two means (Teachers' $M=3,85$; Students' $M=3,83$ ) (See the table below). As shown in Table 10, teachers reported higher perceptions of intercultural learning than teachers' expectations. To examine the significant difference between their teachers' perceptions and students' expectations, independent samples t-test was run (Table 11).

Table 10. Descriptive statistics of the teachers' perceptions and students' expectations regarding intercultural learning

\begin{tabular}{lllll}
\hline & Groups & $\mathrm{N}$ & Mean & Std. Deviation \\
\hline \multirow{2}{*}{ Intercultural learning } & Teachers & 25 & 3,85 &, 266 \\
& Students & 26 & 3,83 &, 421 \\
\hline
\end{tabular}

Table 11 shows the results obtained from the independent samples t-test. As indicated, regardless of the slight difference indicated previously between the means of the two groups (Teachers' $M=3,85$ and Students' $M=3,83$ ), the t-test results indicate that the means of the two groups are not significantly different $(\mathrm{p}<0.05)$, and so there is no significant difference between teachers' perceptions and learners' expectations regarding intercultural learning, $\mathrm{t}(48)=.31, p=, 757$.

Table 11. Independent sample t-test results

\begin{tabular}{l|l|l|l|l|l}
\hline & \multicolumn{6}{|l}{ t-test for Equality of Means } \\
\cline { 2 - 7 } & $\mathrm{T}$ & $\mathrm{Df}$ & Sig. (2-tailed) & $\begin{array}{l}\text { Mean } \\
\text { Difference }\end{array}$ & Std. Error Difference \\
\hline Intercultural learning &, 311 & 48,961 &, 757 &, 028 &, 091 \\
\hline
\end{tabular}

\section{Discussion}

The ultimate objective of the present study was to compare teachers' perceptions with students' expectations regarding intercultural learning. The study also aimed at exploring teachers' perceptions and students' expectations regarding intercultural learning mainly, the cultural aspects of language teaching, the techniques used to instruct culture, the cultural topics covered, and the assessment methods used. Based on the descriptive and inferential statistics, the findings indicated that most of the teachers held positive perceptions by showing a high degree of agreement with 
different aspects of intercultural learning namely, the cultural aspects of language teaching, the cultural topics covered, the techniques, and the assessment methods used in intercultural learning. Regardless of students' disagreement with some aspects of intercultural learning, the results revealed that they showed positive and high expectations about most of the aspects. Furthermore, on the basis of independent samples t-test, the results corroborated that the means of the two groups are not significantly different, and thus there is no significant difference between teachers' perceptions and learners' expectations regarding intercultural learning.

A large majority of teachers showed positive perceptions regarding the cultural aspects of language teaching. The results indicated that the teachers and students positively view that developing students' attitudes, knowledge, and skills as well as establishing similarities and differences between learners' own culture and the target culture stand as a necessity for the development of intercultural awareness (Council of Europe, 2001). The findings also suggested that raising learners' awareness of misunderstandings, which arise in different intercultural encounters, enables them to withhold negative prejudices (Byram, 1997; Deardorff, 2004). Students, on the other hand, highly expected teachers to create an intercultural environment where learners can have the opportunity to experience and interact in crosscultural environment. This remains one of the major objectives of intercultural learning (Liddicoat et al., 2003). This correspondence between teachers' perceptions and students' expectations lead to the conclusion that teachers and learners encourage the development of intercultural competence within the classroom to prepare learners to function appropriately in diverse intercultural encounters.

The results also revealed that teachers' perceptions and students' expectations were found to be positive. Yet, the majority of students showed high expectations regarding the activities that encourage discussions and debates, but still $30 \%$ of them showed low expectations regarding the writing of diaries/journals of their intercultural learning experience at home (portfolios), which is highly recommended in the literature (e.g., Byram, 1997; Byram et al., 2009; Council of Europe, 2001; Lázár at al., 2007). A significant portion of teachers view the activities, which involve discussions, critical incidents, and scenarios and portfolios, interesting to be considered in by teachers in the classroom. This indicates that teachers' perceptions do not match with students' high expectations regarding the intercultural learning techniques and activities that aim at developing intercultural competence. Students, however, seemed to lack understanding of intercultural learning regarding the most recommended and effective techniques used to develop intercultural competence, namely portfolios and critical incidents/scenarios.

The results turned out that both teachers and students showed their interest in learning about perspectives, practices, and products of the target culture, which reflect the criteria upon which the individual can evaluate his/her culture and the other culture (Byam, 1997). Yet, while a large majority of students highly expect to receive information that is true and authentic, a significant amount of teachers showed inclination to the teaching of products of the target culture. This inconsistency shows that some teachers lack knowledge about the requirements of intercultural learning. As for the assessment methods, most of the students highly expect to be evaluated through psychometric tests and interviews. The majority of teachers agreed that objective and subjective assessment methods should be used namely psychometric tests, interviews, and portfolios as the most prominent assessment tools to evaluate students' intercultural competence. Overall, the results show that both teachers and students' responses correspond to each other regarding the implementation of formative/summative and objective/ subjective assessment methods. In alignment with Belli's (2018) findings, students exhibited high expectations with regard to cultural content covered and the assessment tools used. However, students tend to show a lack of understanding concerning the utilization of portfolios either as an assessment method of intercultural competence or as an activity to help them reflect on their intercultural experience (Byram et al., 2009).

The findings of the present study support Hui's (2010) conclusions in that regardless of the teachers' lack of knowledge about some aspects of intercultural learning, it was generally shown that the results associated with teachers' perspectives of intercultural teaching in terms of the cultural topics they favor to teach in the classroom, the techniques they use to teach culture, and finally their attitudes towards intercultural communicative competence were found to be positive and thus align with the specifications addressed in the literature (Tran \& Seepho, 2014). In constant with Hui's (2010) findings, the results revealed teachers' willingness and readiness to engage in cultural teaching while some problems were observed in their perception of some aspects linked with the activities employed, the assessment methods used, and the cultural teaching practices. The findings also go hand in hand with Farooq, Soomro, and Umer's (2018) results, which revealed that teachers are aware of integrating culture and language in their teaching. 


\section{Conclusion}

Overall, despite the mismatches found between teachers' and students' perceptions with regard to different aspects of intercultural learning, the t-test results indicated that the difference found between the means of both groups is not significant. We come to the conclusion that teachers' perceptions of intercultural learning correspond with students' expectations. Add to this, other conclusions can be drawn from the results obtained. First, this study has shown that the teachers understand the notion of intercultural learning regarding the cultural aspects of language teaching, the cultural content covered, the techniques, and the assessment methods used. Second, they perceive intercultural learning as important and necessary for students to function appropriately in different intercultural encounters. Third, students demonstrate an understanding of intercultural learning regardless of their low expectations with respect to some techniques and assessment methods.

The present study provides several implications. First, despite the teachers' positive perception of some aspects of intercultural learning, it was found that their understanding of intercultural learning is still to be developed. Thus, intercultural training seminars on the intercultural teaching methodology should be held to help teachers be aware of the significance of the role of culture in English Language Teaching (ELT) and understand intercultural learning and its components that should be incorporated. Second, university teachers should construct an intercultural framework in order to help them understand how to choose and integrate their culture into ELT effectively, to set appropriate objectives, to assess students' intercultural competence, to cover relevant cultural content, and to implement effective techniques that aim to develop intercultural competence. Third, teachers should always reflect on their understanding of intercultural learning and the way they teach culture in order to meet students' needs and expectations. Fourth, it is believed that discrepancies between teachers' and students' perceptions can have negative effects on students' satisfaction with the language class and even on their ultimate achievement (Alimorad \& Tajgozari, 2016). Therefore, learners should be informed about intercultural learning on the first day class in order to familiarize them with the way it is perceived by their teachers, and thus get them motivated to avoid any likely negative effect on their achievements.

\section{References}

Alimorad, Z., \& Tajgozari, M. (2016). A comparison of Iranian high school teachers' and students' perceptions of effective English teachers. SAGE Open, 6(4), 1-10. Retrieved from https://journals.sagepub.com/doi/full/10.1177/2158244016679212

Belli, S. A. (2018). A study on ELT students' cultural awareness and attitudes towards incorporation of target culture into language instruction. Journal of Language and Linguistic Studies, 14(1), 102-124. Retrieved from https://www.jlls.org/index.php/jlls/article/view/819/347

Brown, H. D. (1994). Principles of language learning and teaching. The USA: Prentice Hall Regents.

Brown, H. D. (2007). Principles of language learning and teaching. New York, NY: Pearson Education.

Byram, M. (1997). Teaching and assessing intercultural communicative competence. Clevedon: Multilingual Matters Publisher. Retrieved from http://www.multilingual-matters.com/display.asp?K=9781853593772

Byram, M., Barrett, M., Ipgrave, J., Jackson, R., \& García, M. C. M. (2009). The autobiography of intercultural encounters. Strasbourg, France: Council of Europe. Retrieved from https://rm.coe.int/context-concepts-andtheories-autobiography-of-intercultural-encounter/168089eb76

Byram, M., Gribkova, B., \& Strakey, H. (2002). Developing the intercultural dimension in language teaching: A practical introduction for teachers. Strasbourg: Council of Europe. Retrieved from https://discovery.ucl.ac.uk/id/eprint/1562524/

Cardona, L., Rico, C., \& Sarmiento, S. (2015). Developing cultural awareness: The text-driven approach as evidence of a good language teaching practice. Creative Education, 6(12), 1360-1385. doi: 10.4236/ce.2015.612137

Corbett, J. (2003). An intercultural approach to English language teaching. Clevedon, England: Multilingual Matters. Retrieved from https://mafiadoc.com/an-intercultural-approach-to-english-language_5987b8171723ddcd69887d2a.html

Council of Europe. (2001). Common European framework of reference for languages: Learning, teaching, assessment. Strasbourg: Cambridge university press. Retrieved from https://rm.coe.int/16802fc1bf 
Cunha, T., \& Gomes, R. (2008). Against the waste of experiences in intercultural learning. Coyote, 13, 8-14. https://pjp-eu.coe.int/documents/42128013/47261485/waste_experiences.pdf/9a621e9c-4179-4985-988c$\underline{0 f 43253 \mathrm{~b} 67 \mathrm{~d} 6}$

Deardorff, D. K. (2004). The identification and assessment of intercultural competence as a students' outcome of internationalization at institutions of higher education in the United States (Doctoral dissertation). North Carolina State University, USA. Retrieved from http://www.lib.ncsu.edu/resolver/1840.16/5733

Farooq, M. U., Soomro, A. F., \& Umer, M. (2018). English language teaching and cultural implications in Saudi Arabia. International Journal of English Linguistics, 8(3), 177-185. doi: 10.5539/ijel.v8n3p177

Huber, J., \& Reynolds, C. (Eds.). (2014). Developing intercultural competence through education. Strasbourg: Council of Europe Publishing. Retrieved from https://rm.coe.int/developing-intercultural-enfr/16808ce258

Hui, H. (2010). An investigation of teachers' perceptions of culture teaching in secondary schools in Xinjiang, China (Doctoral dissertation). Durham University, UK. Retrieved from http://etheses.dur.ac.uk/109/

Israelsson, A. (2016). Teachers' perception of the concept of intercultural competence in teaching English (Master thesis). Stockholm University, Stockholm, Sweden. Retrieved from http://www.divaportal.org/smash/record.jsf?pid=diva2\%3A940669\&dswid=6233

Jokikokko, K. (2010). Teachers`intercultural learning and competence (Doctoral dissertation). University of Oulu, Ouluensis. Retrieved from http://jultika.oulu.fi/Record/isbn978-951-42-6370-5

Kramsch, C. (1993). Context and culture in language teaching. Oxford: Oxford University Press.

Lafraya, S. (2011). Intercultural learning in non-formal education: Theoretical frameworks and starting points. Strasbourg: Council of Europe Publishing. Retrieved from http://republikamladi.reactororg.webfactional.com/media/download-files/megjunarodniistrazhuvanja/9501_Intercultural_learning_Lafraya_Final.pdf

Lázár, I., Huber-Kriegier, M., Lussier, D., Mtei, G. S., \& Peck, C. (2007). Developing and assessing intercultural communicative competence: A guide for language teachers and teacher educators. Strasbourg: Council of Europe Publishing. Retrieved from https://archive.ecml.at/mtp2/publications/B1_ICCinTE_E_internet.pdf

Leutwyler, B., Mantela, C., Petrović, D. S., Dimitrijević, B. M., \& Zlatković, B. (2014). Teachers' beliefs about intercultural education: Different levels of intercultural sensitivity in schooling and teaching. Educational Research, 5(8), 280-289. doi: http:/dx.doi.org/10.14303/er.2014.196

Liddicoat, A. J., Papademetre, L., Scarino, A., \& Kohler, M. (2003). Report on intercultural language learning. Canberra: Department of Education, Science and Training. Retrieved from https://www1.curriculum.edu.au/nalsas/pdf/intercultural.pdf

Neuner, G. (2012). The dimensions of intercultural education. In J, Huber (Ed.), intercultural competence for all: preparation for living in a heterogeneous world (pp. 11-49). Council of Europe Publishing: Strasbourg. Retrieved from https://rm.coe.int/intercultural-competence-for-all/16808ce20c

Richards, J. C., \& Schmidt, R. (2010). Longman dictionary of language teaching and applied linguistics $\left(4^{\text {th }} \mathrm{Ed}\right)$. London: Longman.

Sandu, O. N. (2013). Intercultural learning: An educational approach to social transformation. Journal plus education, 9(2), 81-89. Retrieved from https://uav.ro/jour/index.php/jpe/article/view/129

Shemshadsara, Z. G. (2012). Developing cultural awareness in foreign language teaching. English Language Teaching, 5(3), 95-99. doi: 10.5539/elt.v5n3p95

Skopinskaja, L. (2009). Assessing intercultural communicative competence: Tests construction issues. Synergies Pays Riverains de la Baltique, 6, 135-144. https://gerflint.fr/Base/Baltique6/liljana.pdf

Stern, H. H. (1992). Issues and options in language teaching. Oxford University Press.

Tran, T. Q., \& Seepho, S. (2015). An instruction design model for intercultural language teaching: a proposed model. Humanising Language Teaching, 17(1). https://old.hltmag.co.uk/feb15/mart03.htm 
Vigier, M., \& Le Floch, N. S. (2011). Promoting cultural awareness in an international business program through foreign language communication. Global Business Languages, 16(6), 43-58. Retrieved from https://docs.lib.purdue.edu/gbl/vol16/iss1/6

Yeganeh, M. T., \& Raeesi, H. (2015). Developing cultural awareness in EFL classrooms at secondary school level in an Iranian educational context. Procedia-Social and Behavioral Sciences, 192, 534-542. Retrieved from https://doi.org/10.1016/j.sbspro.2015.06.084

Zhao, B. (2010). How to enhance cross-cultural awareness in TEFL. Cross-Cultural Communication, 6(2), 100-104. doi: http://dx.doi.org/10.3968/j.ccc.1923670020100602.012 